\title{
Emilia Paprzycka*
}

iD https://orcid.org/0000-0003-3198-958X

\section{Edyta Mianowska**}

iD https://orcid.org/0000-0002-0949-2641

\section{WHICH WOMEN (DON'T) LEAVE AND WHICH MEN (DON'T) STAY? GENDER AND THE DIVERSITY OF FORMS AND THE TEMPORALITY OF CONTEMPORARY INTIMATE RELATIONSHIPS}

\begin{abstract}
The article focuses on relationship experiences in the light of the diversity of relationship forms, relationship length and the attitude of partners to relationship permanence. The conceptual framework was determined by the sociotemporal perspective, and the analysis was carried out with reference to concepts employed in the fields of the sociology of the family, the sociology of intimacy, the sociology of gender and the sociology of time. The aim of the study was to determine the relationship between the socio-demographic characteristics of women and men and their relationship experiences, the diversity of relationship forms and their length, as well as their readiness to stay in a relationship or leave in a crisis situation. The research was carried out using the diagnostic survey method on a representative sample of adult Poles in January 2018. Gender has been shown to differentiate the length of relationship and the attitudes to relationship permanence. It was found that women stay in shorter relationships more often than men. It was also found that the experiences of women with different types of relationships are more diverse when linked to their social status than the experiences of men. Four types of orientation to the (im)permanence of relationships were identified. It was established that men's readiness to leave depends on their age, education and selfassessment of their financial situation, whereas women's decision to leave depends on their age, education and socio-occupational category.
\end{abstract}

Keywords: intimate relationships, breakups, women, men, sex, gender.

* PhD hab., Department of Sociology, Institute of Sociological Sciences and Pedagogy, Warsaw University of Life Sciences, ul. Nowoursynowska 166, 02-787 Warsaw, e-mail: emilia_paprzycka@sggw.edu.pl

** PhD, Department of Social Research Methodology, Faculty of Pedagogy, Psychology and Sociology, University of Zielona Góra, al. Wojska Polskiego 69, 65-762 Zielona Góra, e-mail: e.mianowska@ips.uz.zgora.pl 


\section{Introduction}

The article focuses on the experiences of being in a relationship in the light of the diversity of relationship forms, relationship length and the attitude of partners to relationship permanence. The conceptual framework was determined by a sociotemporal perspective and the analysis was carried out in reference to concepts employed in the fields of the sociology of family, the sociology of intimacy, the sociology of gender and the sociology of time. It was assumed that an important factor and context for the interpretation of transformations in matrimonial life are changes both in relations between the sexes and in the area of social time. The argument for adopting such a perspective stemmed not only from the fact that temporality plays a key role in the experience of living together, but also from the way it changes the current biographical order, also in the realm of intimate biography (Lahad 2011; Strzelecka 2017; Paprzycka 2019).

The presented study contributes to current research on changes in maritalfamily life, which assumes that the primary indicators of contemporary intimate relationships are related to the changes in their dynamics, i.e. their formation, course and duration (Kaufmann 1993; 2012; Jamieson 1998; 2008; Gidden s 2006; 2010; Schmidt 2015). The article focuses on two of the features of relationships that are perceived as the most characteristic of modern relationships, namely their temporality (Jamieson 2008; Bauman 2003; Lahad 2011; Musiał 2015; Strzelecka 2017) and the orientation of partners towards maximizing the fulfilment of their own/ individual needs (Bawin-Lergos 2004; Giddens 2006; Jamieson 2008). It is emphasized that the main function of a modern relationship is to meet needs of an erotic and emotional nature. As a result, if the individual needs and expectations typically involved in an intimate relationship are not met, it can be interrupted at any time (Bawin-Lergos 2004). According to this approach, the nature of an intimate relationship is determined by how the conditions set by partners are met, with the dynamics being based on gratification and constant striving for compromises between the fulfilment of the partners' individual needs and the need for the security that a relationship with another person provides (Giddens 2006). A feature of modern relationships is that they are created not due to external coercion or social expectations, and their functioning is not regulated by top-down norms and rules, but is rather shaped according to the will of the participating individuals. Anthony Giddens argues that nowadays individuals enter into a relationship for themselves, i.e. for what each of them can derive from a lasting relationship with another person (Giddens 2006: 75). This means that the individuals who participate in such a relationship permanently monitor the state of this relationship and attempt to transform it when it ceases to meet their expectations or, as a last resort, they end their participation in the relationship. According to Giddens, the "romantic idea of love that lasts forever", which had 
been binding until recently, is giving way to "the idea of pure love as long as it lasts". Therefore, as Jean-Claude Kau fmann (2012: 120-122) observes, the basic problem faced by contemporary couples is that they are permanently deciding whether to stay together or break up, hence modern relationships can be seen as relationships that are constantly being constructed and deconstructed.

The changes in marital-family life are accompanied by changes in social definitions, norms and social expectations. The literature on this topic emphasizes that the history of changes in intimate life is embedded in the transformations that took place and are taking place in pre-modern, modern and post-modern societies (see Beck, Beck-Gernsheim 1995; Giddens 2006; 2007; Jamieson 2008). The intimacy created today has emerged because three models of intimacy (traditional, modern and post-modern) are being applied simultaneously (Plummer 2003). As a result, analyzing contemporary intimate relationships poses a challenge for researchers, because while traditional relationships and modern relationships are relatively well defined, there is as yet no precise description for post-modern relationships. Studies on changes in martial life focus primarily on changes in the structure of the family. It is believed that new forms of being together are a symbol of a postmodern condition expressed by the increase in diversity and fluctuation of intimate relationships (Stacey 1990). According to Ulrich Beck and Elizabeth Beck-Gernsheim (2002: 204), we are now entering into optional relationships within families, which are very difficult to identify in an objective and empirical way, because they are a matter of subjective perspectives and decisions. Lyn Jamies on (2008) proposes two analytical perspectives: optimistic and pessimistic. The former assumes that intimate relationships remain the essence of private life, but the marriage-based family is losing its primary importance as a norm and ideal. In this conception, it is no longer the family but rather one or more satisfying relationships that are at the centre of personal life. According to Jamieson, despite the fact that permanent, long-term intimate relationships are still most often chosen - including informal ones - a variety of intimate lifestyles is inevitably developing. In the second perspective, these changes are viewed in terms of the collapse of the normative and religious foundations of marriage. She attributes the main reason for the changes to the negative effects of individualism, which in modern societies encourages the free choice of the object of love, and in post-modern relationships leads to the breakup of relationships. In this pessimistic interpretation, the importance of intimacy is diminished due to the influence of a consumer culture that promotes self-centred and self-isolating individualism.

The transformation of marital-family life in the era of postmodernity is often explained by the fact that people are now looking for ways of being together that are better suited to current living conditions. These changes can be also considered from the perspective of social time. Some authors assert that well-known models of linear and cyclic time, developing within long-term sociocultural processes, clearly result in established forms of marital-family life, 
i.e. multi-generational, nuclear, neoliberal and contemporary, the so-called cyclical (see Strzelecka 2017). The nuclear family model is related to the linear perception of time, which is characterized by an inflexible model of events: birth - education - work - marriage - family - retirement - death (Dychtwald 2003). This entails that, in contrast, contemporary intimate relationships are seen as temporal arrangements in which the practised models of being together are characterized by much greater mobility and diversity (Lahad 2011), while the basic attributes of marital-family life, e.g. a marriage certificate, are no longer associated with them (Trybulec 2009). It is noted that the elements formerly associated with living together as a couple are being replaced by emotional and financial bonds (see Renzetti, Curran 2008), and the increasing number of divorces and subsequent marriages confirm the change in the model of marital-family life from linear to cyclical. There is no single dominant relationship in this model, and starting a family and having children are no longer the natural consequences of going through subsequent biographical stages, but are becoming a matter of choice (Collier, Rosaldo, Yanagisako 2007; Strzelecka 2017). In this model, the intimate life of each individual may change several times - the individual may return to a previous phase or start living in a new configuration outside of formalized intimate relationships (Strzelecka 2017).

The analyses proposed in the article fit into the "optimistic" perspectives of research on changes occurring in marital-family life, which oppose conceiving of these changes in terms of family crisis and propose considering the intensive changes in this area as the emergence of new practices in the field of redefining relationships, in terms of functions and types (see de Singly 1994; 1996; Brow n 2004; Kiernan 2004; Kaufmann 2005; Silverstein, Auerbach 2005; Slany 2006; Giddens 2007; Majka-Rostek 2008; Kwak, Bieńko 2012; Kwak 2014; Illouz 2016; Mizielińska 2017). This research focused solely on intimate relationships because attention has been drawn to the increasingly autonomous nature of such relationships in relation to family relationships for many years (Lenz 2006). This approach is becoming increasingly popular among researchers and is exemplified, for example, in the form of a theoretical-research programme proposal (see Schmidt et al. 2018).

The current study adopts the conceptualization of an intimate relationship put forward by Jean-Claude Kaufmann (2012: 120-122), who defines such a relationship as a continuous process, in which the formation of a couple emerges as a coincidence, and the relationship length results from a lack of motivation to make a decision to end it. In this approach, the relationship between a modern couple appears to be something lacking stability and having a complicated structure. At the same time, Eva Illouz (2016) and other researchers, for instance Lyn Jamies on (2008), explain the increase in the number of breakups (divorces, separations) not in terms of crisis, but as indicating a rise in the importance of a relationship. According to Illouz, an intimate relationship has now become the 
main component of a person's biography and has taken on a meaning it never had before. In consequence, this leads to an increase in the demands placed on the partner and requirements with regard to the quality of the relationship. Despite the impermanence of relationships, it is argued that a stable and satisfying relationship is still an important reference point in the evaluation of intimate relationships, both for couples and people currently not in a relationship (Kaufmann 2012; Jewdokimow, Garncarek 2007; Paprzycka 2019). The increase in the number of breakups can, therefore, be seen not as people giving up the search for a lifetime companion, but rather as a lack of consent to a malfunctioning relationship (Jamieson 2008). Interpreted from this perspective, high divorce rates reflect the growing importance attached today to a good marriage and are treated as one of the factors that transform marriage. At present, people who decide to get married consider the possibility of separation and do not expect to live together until they die (Walerstein, Blakeslee 1989). The greater likelihood of separation also increases the efforts made by partners to prevent this from happening.

In this article, the term "intimate relationship" is used for all types of intimate relationships that fall into the category of an intimate couple; it does not only apply to marriages. The analyses were conducted from the perspective that treats an intimate couple as a social relationship (Sztompka 2012). They focused on the relationship between the social position of the partners in an intimate relationship (their status) and the framework of an intimate relationship as defined by its form, the patterns of its course and its duration. Gender was made a main analytical category as it is crucial for the positioning of women and men in society. The study adopted a functional approach to gender (Holmes, Marra 2011; Wharton 2006) assuming its stratification significance (Acker 1990; Ferree 2003; Martin 2004). The perspectives of the analysis drew on two different but complementary concepts - one developed by Anthony Giddens $(2006$; 2007) and the other one created by Ulrich Beck and Elizabeth Beck-Gernsheim (1995), who perceive the transformation of marital-family life in relation to changes in the relations between the sexes. Giddens points out that the increase in freedom and equality, which translates into changes in the area of intimate life, weakens inequalities between men and women. He predicts that more and more people will be looking for a new type of relationship, a so-called "pure relationship", which by definition is a relationship between equal people. However, Beck and BeckGernsheim believe that the increase in freedom and equality is, to a large extent, purely theoretical and postulative. They point to restrictions in this area, which are located primarily in the social structure. These barriers also result from tensions between the requirements of the labour market and requirements related to family life. According to these authors, despite the emergence of new values, society as a whole does not keep up with progressive and egalitarian beliefs, especially in the context of changing gender relations. 
The theoretical framework of the research covered in the article is indebted to the socio-cultural theory of Raewyn Connell (1987; 2013), in which gender is defined as a specific structure and institution essential for shaping social stratification and access to various types of capital. In this approach, gender structures social life in its various dimensions (micro-, meso- and macrostructural) and is a gradation structure. In terms of social process and practice, it is created and reproduced by social orders, and places different categories of women and men in various spaces and positions. It is assumed that there are individual differences within the male and female community. The presented research takes into account the status differentiation within the gender category. The analyses were aimed at identifying the structural consequences of gender differences in the area of experience in relationships - the diversity of forms and duration as well as orientation on their permanence.

\section{Methodological assumptions}

The research was of a descriptive and explanatory nature, and its purpose was to determine the relationship between the socio-demographic characteristics of women and men, their relationship experiences, and their readiness to remain in a relationship or break up in a crisis situation. The research sought answers to the following research questions: 1) Does gender differentiate relationship experiences and the readiness to remain in a relationship or break up when there is a crisis in the relationship and dissatisfaction with it? 2) How do the features of social status among women and men (with gender understood here structurally) differentiate relationship experiences and the readiness to remain in a relationship or break up when crisis and dissatisfaction arise?

The following hypotheses were made:

H 1. Gender differentiates relationship experiences and the readiness to remain in a relationship or break up when there is a crisis in the relationship and dissatisfaction with it.

$\mathrm{H} 2$. The characteristics of social status differentiate relationship experiences and the readiness among women and men to remain in a relationship or break up in times of crisis and dissatisfaction.

\section{Data}

The research was carried out in 2018 on a representative sample of 951 adult residents of Poland (18-66 years old) ${ }^{1}$, which was drawn from the National Register of Polish citizens (PESEL). In order to control the territorial dispersion,

${ }^{1}$ The research was carried out under the project: "Dynamics of Poles' intimate relationships" in 2017-2018. Purposeful grant from the Ministry of Science and Higher Education. Project manager: Emilia Paprzycka. 
the random selection was stratified in proportion to the voivodships and the size of the place of residence ( 80 layers). $53 \%$ of respondents were women, $47 \%$ of them were men. The study was conducted in the subjects' homes by means of computer-assisted direct interviews, so-called CAPI (Computer Assisted Personal Interview).

\section{Variables and indicators}

The set of characteristics defining gender in the adopted structural approach was determined by the research questions, which employed socio-demographic independent variables such as age, place of residence, education, professional category, financial situation (the objective indicator of which was the amount of monthly income per person; the subjective indicator being the subjects' selfassessment of their financial situation) $)^{2}$. Gender was treated both as an independent variable and as a criterion for the division of respondents.

A dependent variable was the relationship experience, the components of which were conceptualized from the intimate relationship status and the length of the relationship. Intimate relationship status indicators were operationalized according to the criterion of being in a relationship. The basic categories were being married, being in an informal relationship (cohabitation) and being without a partner (single life). The relationship length was determined on the basis of the categorized duration of the relationship.

Another dependent variable was the readiness to remain in a relationship or break up in the event of crisis and dissatisfaction. To this end, a composite indicator was constructed: the scale of orientation towards the (im)permanence of the relationship in the event of dissatisfaction. It was based on two dimensions. The first dimension of temporality versus permanence was the readiness to remain in a relationship, which was measured by the number of arguments for staying in the relationship despite the lack of satisfaction with $i^{3}$. The second dimension: uncompromisingness versus conciliation was the readiness to end the relationship, which was measured by the number of possible reasons for leaving the partner in a crisis situation ${ }^{4}$.

2 The structure of the socio-demographic characteristics is presented in Table 1.

3 The reasons for staying in an unsatisfactory relationship proposed for assessment, in addition to the reasons of a pragmatic nature, included arguments that referred to commitments made during the marriage vows, defining marriage as an inseparable relationship based on love. In total, the list includes eight reasons that may influence the continuation of an unsatisfactory relationship: (1) fear of friends and family's opinion, (2) belief in the inseparability of marriage, (3) best interests of their children, (4) love for a partner, (5) joint financial liabilities (credits, loans), (6) financial dependence on the partner, (7) convenience, reluctance to change, (8) fear of loneliness.

${ }^{4}$ Among the reasons for deciding to separate proposed for assessment, the most frequently mentioned reasons for divorce were taken into account (Eurostat 2015). The respondents were also assessed for potential breakups, the source of which may be functioning in a long-term relationship or 
The position of the respondent at every dimension was the basis for recognizing the readiness to remain in a relationship or break up in the event of crisis and dissatisfaction 5 . Four types of orientation towards the (im)permanence of the relationship were singled out:

1. oriented towards relationship permanence, but an uncompromising attitude in a crisis situation (ambivalence). This type describes respondents who indicated many reasons to stay in an unsatisfactory relationship, yet at the same time many reasons to end such a relationship. Simultaneously indicating many arguments "for" and "against" indicates the absence of an unequivocal attitude to ending an unsatisfactory relationship, and may be a predictor of the readiness to negotiate.

2. oriented towards the temporary nature of the relationship, and an uncompromising attitude in a crisis situation (acceptance). This type describes respondents who would consider many reasons to leave their partner, while few arguments could prompt them to continue a failed relationship. This configuration of reasons indicates a great potential for ending a relationship and separating from a partner.

3. oriented towards the temporary nature of relationships, but conciliation in a crisis (indifference). This type describes respondents who indicated a few reasons that would lead them to leave and a few reasons that they would consider when thinking about whether or not to remain in an unsatisfactory relationship. It is a situation that is rather conducive to maintaining the status quo of the relationship and displays passivity in approaching the decision to break up. Although the termination of the relationship is not ruled out (reasons for separation are identified, although there are a few), the number of arguments for making the decision to break up, however, do not form a sufficient basis for making such a decision. Although termination of the relationship is not ruled out (there are a few reasons to stay), there are also many reasons for leaving the partner.

4. oriented towards relationship permanence, and conciliation in a crisis situation (inertia). The respondents who are characterized by such an attitude to the (im)permanence of a relationship would consider a lot of arguments for continuing the failed relationship and at the same time see a few reasons for abandoning their partner if problems arose in the relationship. In this case, the relationship does not seem uncertain, as the arguments raised reinforce the argument for maintaining the relationship.

lack of loyalty. The respondents evaluated the following reasons: (1) lack of time for each other, (2) difficulties in communicating, frequent quarrels, (3) burnout of the relationship, distance from each other, (4) partner's addiction (e.g. alcohol, drugs, gambling), (5) physical or psychological violence, (6) decrease in the partner's attractiveness - age-related appearance changes, neglect, (7) sexual mismatch, (8) one-time betrayal by the partner, (9) long-term affair of the partner, (10) financial problems of the partner, (11) inability of the partner to have children, (12) long-term illness of the partner.

${ }^{5}$ For both dimensions, a dichotomous division of the number of reasons was established. It was assumed that the indication of more than four reasons means high readiness to part, and failure to indicate any or at most four means low readiness to part. 


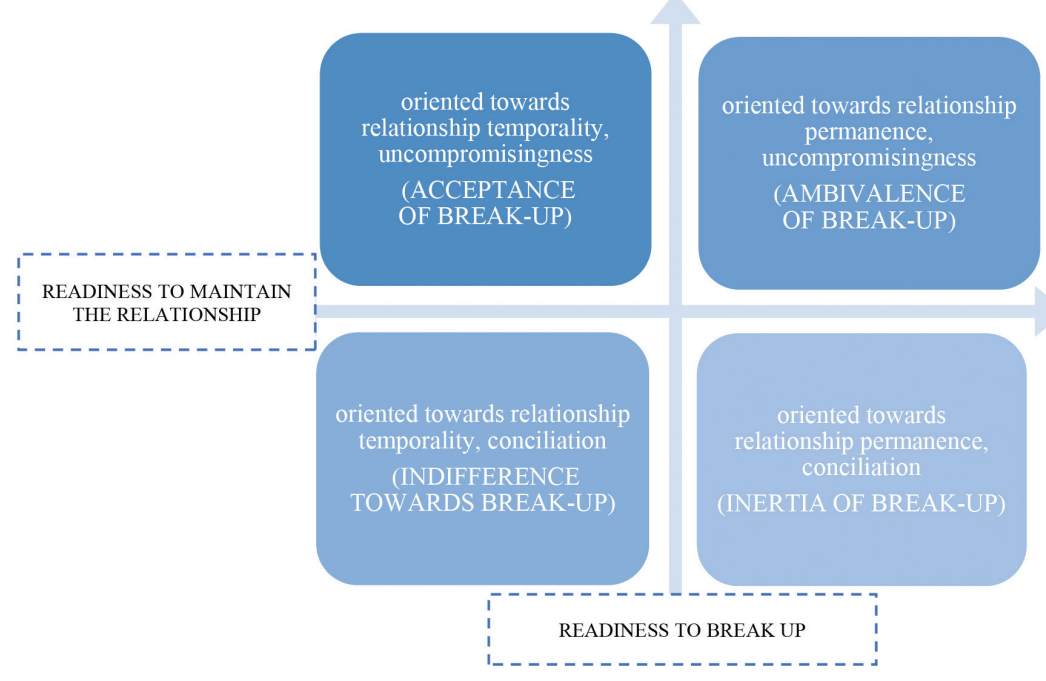

Diagram 1. The typology of orientation towards the (im)permanence of a relationship in the event of crisis or lack of satisfaction

Source: authors' own research

\section{Statistical tools}

The assumed relationship between the distribution of nominal variables (intimate relationship status, relation to the (im)permanence of a relationship), was checked using the chi-squared test, and the distributions of the ordinal variable (relationship length) in several groups were compared using the non-parametric Kruskall-Wallis H test. The differences between the groups for multiple comparisons and two groups were tested using the Mann-Whitney U test. The strength of the relationship was analyzed depending on the level of measurement and the number of categories of correlated variables, based on the V-Kramer contingency coefficient and Kendall tau-b and tau-c coefficients. The studies assumed the significance level alpha $=0.05$, and in the case of multiple comparisons the Bonferroni correction for the significance level was taken into account. The calculations were made in the PS IMAGO statistical package.

\section{Results}

\section{Gender and relationship experiences}

The relationship experiences have been described in two dimensions: the intimate relationship status and the relationship length. All the categories of intimate relationship status were noted among the respondents. The majority of the respondents 
(71.8\%) were people in relationships. These were both formal relationships - marriages (62.5\%; civil - 6.7\%; religious - 55.8\%) and informal $(9.3 \%)$. $28.2 \%$ of respondents were without a partner. Gender did not differentiate the structure of the intimate relationship status (Chart 1).

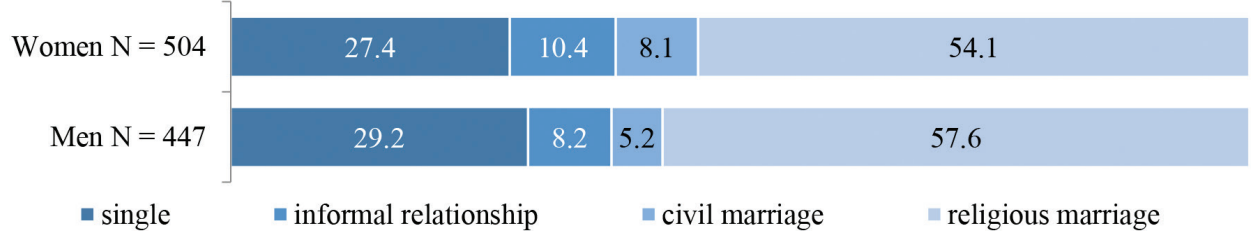

Chart 1. The structure of the intimate relationship status among men and women Source: authors' own research

The second dimension of the relationship experience - the relationship length, was a feature the distribution of which was statistically significantly dependent on gender ( $\mathrm{chi}=16.20 ; \mathrm{df}=5, \mathrm{p}=0.006 ; \mathrm{V}=0.154$ ). Among the respondents, people in the longest relationship dominated both among men and women. Women were more likely to have shorter relationships than men. More men than women were in longer relationships lasting over 25 years (Chart 2).

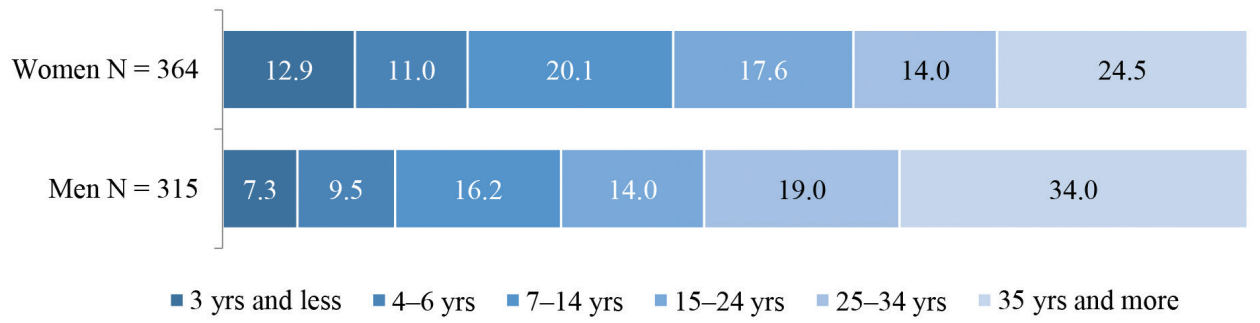

Chart 2. The structure of the relationship length among men and women

Source: authors' own research

In accordance with the adopted theoretical concept of socio-cultural gender, in order to identify individual differences within the population of women and men, analyses regarding the relationships between the socio-demographic characteristics of the respondents and the relationship experience were conducted separately for women and men. Such analytical proceedings allowed the differences and similarities in this regard to be determined, not only between men and women, but also within the gender category.

The intimate relationship status of men was differentiated by three sociodemographic features: age, education and belonging to a socio-occupational group. The age of the respondents ( $\mathrm{chi}=107.974 ; \mathrm{df}=10, \mathrm{p}<0.000 ; \mathrm{V}=0.348)$ and the position in the socio-occupational structure $(\mathrm{chi}=65.324 ; \mathrm{df}=12, \mathrm{p}<0.000$; $\mathrm{V}=0.271)$ most strongly correlated with the intimate status. The weakest relationship was recorded in case of education $(\mathrm{chi}=31.267$; $\mathrm{df}=6, \mathrm{p}<0.000$; 
$\mathrm{V}=0.187)$. The intimate relationship status among men was not differentiated by the place of residence, or by income and assessment of financial situation.

The intimate relationship status of women was differentiated by most of the analyzed socio-demographic characteristics. A statistically significant relationship was only not recorded for income. Similarly to men, the strongest correlation occurred in the case of age (chi $=134.771 ; \mathrm{df}=10, \mathrm{p}<0.000 ; \mathrm{V}=0.367)$ and belonging to a socio-professional category ( $\mathrm{chi}=77.061 ; \mathrm{df}=12, \mathrm{p}<0.000$; $\mathrm{V}=0.277)$ ). Weaker relationships were found in the case of: education ( $\mathrm{chi}=39.392 ; \mathrm{df}=6, \mathrm{p}<0.000 ; \mathrm{V}=0.198)$, the place of residence $(\mathrm{chi}=24.950$; $\mathrm{df}=6, \mathrm{p}<0.000 ; \mathrm{V}=0.158)$ and self-assessment of financial situation $(\mathrm{chi}=34.303$; $\mathrm{df}=4, \mathrm{p}<0.000 ; \mathrm{V}=0.185$ ).

In the light of these results (Table 1), it can be stated that in the case of men, those in marriages were primarily from older age groups, with higher or vocational education, representatives of management and specialists, as well as retirees and pensioners. However, being in an informal relationship or remaining without a partner was associated with a young age. These types of intimate relationship status best describe the youngest respondents. Having primary/ lower secondary or secondary education and belonging to the category of persons employed as middle level staff and working in administration or services was associated with being single. On the other hand, being in an informal relationship was associated with a low level of completed education (having at most vocational education).

Based on the results obtained among the women, it can be concluded that marriage was most common among women who were mature (45-54 years old) with higher education and who were residents of large cities (100-500 000 inhabitants). They were most often women who assessed their financial situation as good, representing socio-occupational groups such as management and specialists, the self-employed, farmers, housewives and the unemployed.

Single life was most often experienced by women from the youngest and oldest age category: pupils, students, retirees or pensioners, most often with primary/ lower secondary or secondary education. This intimate relationship status was usually accompanied by the lowest self-assessment of one's own financial situation. Without a partner were, in particular, inhabitants of villages, medium-sized towns (20-100 000 inhabitants) and larger cities (over 500000 inhabitants).

Informal relationships were most typical for the youngest women from medium-sized cities (20-100 000 inhabitants). Being in a relationship not confirmed by marriage vows was also more likely to affect young women, pupils and students, and women with at least secondary education. 
Table 1. The intimate relationship status and socio-demographic characteristics among women $(\mathrm{N}=504)$ and men $(\mathrm{N}=447)$. Data in percentages

\begin{tabular}{|c|c|c|c|c|c|c|c|c|c|}
\hline \multirow[b]{3}{*}{ Characteristics } & \multirow[b]{3}{*}{ categories } & \multirow[b]{2}{*}{ W } & \multirow[b]{2}{*}{$\mathrm{M}$} & \multicolumn{3}{|c|}{ Women } & \multicolumn{3}{|c|}{ Men } \\
\hline & & & & Single & $\begin{array}{l}\text { Inform. } \\
\text { relation }\end{array}$ & Married & Single & $\begin{array}{l}\text { Inform. } \\
\text { relation }\end{array}$ & Married \\
\hline & & 53.0 & 47.0 & 27.4 & \begin{tabular}{ll|}
10.4 \\
\end{tabular} & $\begin{array}{l}62.2 \\
\end{array}$ & 29.2 & 8.2 & $\begin{array}{l}62.6 \\
\end{array}$ \\
\hline \multirow{6}{*}{ Age } & $18-24$ & 7.3 & 8.1 & 47.2 & 47.2 & 5.6 & 73.0 & 21.6 & 5.4 \\
\hline & $25-34$ & 20.9 & 17.6 & 12.4 & 17.1 & 70.5 & 36.7 & 22.8 & 40.5 \\
\hline & $35-44$ & 19.7 & 17.6 & 21.4 & 5.1 & 73.5 & 25.6 & 3.8 & 70.5 \\
\hline & $45-54$ & 14.1 & 16 & 15.5 & 4.2 & 80.3 & 20.0 & 7.1 & 72.9 \\
\hline & $55-64$ & 17.1 & 19.4 & 25.0 & 6.0 & 69.0 & 27.6 & 2.3 & 70.1 \\
\hline & 65 or more & 21.0 & 21.3 & 50.5 & 2.9 & 46.7 & 18.8 & - & 81.3 \\
\hline \multirow{4}{*}{ Education } & $\begin{array}{l}\text { primary/ } \\
\text { low secon. }\end{array}$ & 18.2 & 19.7 & 48.9 & 8.7 & 42.4 & 43.2 & 3.4 & 53.4 \\
\hline & vocational & 17.9 & 31.9 & 24.7 & 5.6 & 69.7 & 22.4 & 6.3 & 71.3 \\
\hline & secondary & 32.5 & 28.2 & 28.8 & 12.9 & 58.3 & 38.4 & 10.4 & 51.2 \\
\hline & high & 31.5 & 20.2 & 14.6 & 11.4 & 74.1 & 14.4 & 12.2 & 73.3 \\
\hline \multirow{5}{*}{$\begin{array}{l}\text { Place of } \\
\text { residence }\end{array}$} & village & 37.8 & 41.9 & 27.9 & 6.3 & 65.8 & 36.4 & 8.0 & 55.6 \\
\hline & $\begin{array}{l}\text { town } \\
<19000\end{array}$ & 12.9 & 15.8 & 18.5 & 24.6 & 56.9 & 19.4 & 11.1 & 69.4 \\
\hline & $\begin{array}{l}\text { town } \\
20-99000\end{array}$ & 20.2 & 19 & 34.3 & 10.8 & 54.9 & 24.7 & 5.9 & 69.4 \\
\hline & $\begin{array}{l}\text { town } \\
100-499000\end{array}$ & 16.5 & 14.4 & 20.7 & 7.3 & 72.0 & 29.2 & 6.2 & 64.6 \\
\hline & $\begin{array}{l}\text { city } \\
>500000\end{array}$ & 12.5 & 8.8 & 30.6 & 12.9 & 56.5 & 21.6 & 13.5 & 64.9 \\
\hline \multirow[b]{2}{*}{ Income* } & $<2000 \mathrm{zl}$ & 72.5 & 64.8 & 31.3 & 8.0 & 60.7 & 29.9 & 5.2 & 64.9 \\
\hline & $\begin{array}{l}2000 \mathrm{zl} \\
\text { and more }\end{array}$ & 27.5 & 35.2 & 26.3 & 11.7 & 61.9 & 25.5 & 7.3 & 67.2 \\
\hline \multirow{3}{*}{$\begin{array}{l}\text { Financial } \\
\text { situation }\end{array}$} & bad & 6.3 & 5.8 & 56.3 & 12.5 & 31.3 & 40.7 & 3.7 & 55.6 \\
\hline & average & 31.5 & 32.8 & 37.6 & 10.8 & 51.6 & 32.9 & 8.9 & 58.2 \\
\hline & good & 62.2 & 61.5 & 19.5 & 9.9 & 70.6 & 26.1 & 8.1 & 65.8 \\
\hline \multirow{7}{*}{$\begin{array}{l}\text { Socio- } \\
\text { occupational } \\
\text { group }\end{array}$} & $\begin{array}{l}\text { managers and } \\
\text { specialists }\end{array}$ & 13.3 & 10.6 & 16.7 & 9.1 & 74.2 & 12.5 & 6.3 & 81.3 \\
\hline & $\begin{array}{l}\text { middle-level, } \\
\text { services and } \\
\text { office staff }\end{array}$ & 19.3 & 18.8 & 22.7 & 14.4 & 62.9 & 34.1 & 13.4 & 52.4 \\
\hline & $\begin{array}{l}\text { labourers/ } \\
\text { manual workers }\end{array}$ & 8.1 & 14.5 & 29.3 & 9.8 & 61.0 & 27.8 & 9.3 & 62.9 \\
\hline & $\begin{array}{l}\text { self-employed } \\
\text { farmers }\end{array}$ & 7.4 & 9.3 & 13.5 & 8.1 & 78.4 & 23.5 & 13.7 & 62.7 \\
\hline & $\begin{array}{l}\text { housewives, } \\
\text { househusbands } \\
\text { and } \\
\text { unemployed }\end{array}$ & 16.9 & 12 & 14.3 & 9.5 & 76.2 & 55.2 & 13.8 & 31.0 \\
\hline & $\begin{array}{l}\text { retirees and } \\
\text { pensioners }\end{array}$ & 30.7 & 31.8 & 41.3 & 5.2 & 53.5 & 22.9 & 0.7 & 76.4 \\
\hline & $\begin{array}{l}\text { pupils and } \\
\text { students }\end{array}$ & 4.3 & 3.8 & 57.1 & 42.9 & - & 85.7 & 14.3 & - \\
\hline
\end{tabular}

* missing data: men $24.5 \%$; women $21.7 \%$.

Source: authors' own research. 
The socio-demographic characteristics mostly correlated with the length of the intimate relationship of the respondents. Among men, the strongest association was noted between the age and the length of relationship (chi $=251.181$; $\mathrm{df}=5, \mathrm{p}<0.001$, tau-b $=0.768)$. A connection between education and the length of the relationship was also found $(\mathrm{chi}=24.539 ; \mathrm{df}=3, \mathrm{p}<0.001$, tau-c $=-0.271)$. The length of the relationship of the surveyed men depended on the self-assessment of their financial situation ( $\mathrm{chi}=9.484 ; \mathrm{df}=2, \mathrm{p}=0.009$, tau-c $=-0.14)$ and income per person $(\mathrm{z}=-2.537 ; \mathrm{p}=0.011 ; \mathrm{V}=0.271)$. A relationship was also established between men's belonging to a socio-occupational group and the relationship's length $(\mathrm{chi}=163.223 ; \mathrm{df}=6, \mathrm{p}<0.001 ; \mathrm{V}=0.380)$. The connection between the place of residence and the length of the relationship turned out to be statistically insignificant.

Similar associations were also found for women. Both age $(\mathrm{chi}=272.498$; $\mathrm{df}=5, \mathrm{p}<0.001$, tau-b $=0.749)$ and education $(\mathrm{chi}=42.118 ; \mathrm{df}=3, \mathrm{p}<0.001$, tau-c $=-0.292$ ) differentiated the length of the relationship. The length of staying in a relationship depended on the self-assessment of their financial situation (chi $=16.496 ; \mathrm{df}=2, \mathrm{p}<0.001 ; \mathrm{V}=0.186$ ) and the location in the sociooccupational structure (chi $=157.871 ; \mathrm{df}=6 \mathrm{p}<0.001 ; \mathrm{V}=0.361$ ). Among the socio-demographic features included in the study, statistically insignificant differences were obtained in the case of the relationship length and the place of residence, as well as income per person.

Summing up the results of the study (Table 2-5), it can be stated that men from older age groups with lower education, assessing their financial situation as bad or average, with an income per person above $2000 \mathrm{zł}$ were more often in longer relationships. Retirees and pensioners, as well as housekeepers and the unemployed, were in the longest relationships. Men with higher education from younger age categories, as well as pupils and students, were usually in the shortest relationships.

As in the case of men, women who reported being in a longer relationship tended to be from older age categories, with lower education, most often assessing their financial situation as bad or average. Being a retiree, a pensioner, a selfemployed farmer or a manual worker was associated with being in a long relationship. The youngest women, with higher education, studying and assessing their financial situation as good, were in the shortest relationships. 
Table 2. The age and the length of relationship. Mann-Whitney U test results for multiple comparisons among men $(\mathrm{M}, \mathrm{N}=315)$ and women $(\mathrm{W}, \mathrm{N}=364)$ in relationships

\begin{tabular}{|c|c|c|c|c|c|c|}
\hline & Age & $18-24$ & $25-34$ & $35-44$ & $45-54$ & $55-64$ \\
\hline \multirow[t]{5}{*}{ M } & $25-34$ & $\begin{array}{c}z=-3.196 \\
p=0.001\end{array}$ & & & & \\
\hline & $35-44$ & $\begin{array}{c}\mathrm{z}=-4.610 \\
\mathrm{p}<0.001\end{array}$ & $\begin{array}{c}\mathrm{z}=-5.540 \\
\mathrm{p}<0.001\end{array}$ & & & \\
\hline & $45-54$ & $\begin{array}{c}\mathrm{z}=-5.216 \\
\mathrm{p}<0.001\end{array}$ & $\begin{array}{c}\mathrm{z}=-8.228 \\
\mathrm{p}<0.001\end{array}$ & $\begin{array}{c}\mathrm{z}=-6.692 \\
\mathrm{p}<0.001\end{array}$ & & \\
\hline & $55-64$ & $\begin{array}{c}\mathrm{z}=-5.274 \\
\mathrm{p}<0.001\end{array}$ & $\begin{array}{c}\mathrm{z}=-9.242 \\
\mathrm{p}<0.001\end{array}$ & $\begin{array}{c}z=-9.067 \\
p<0.001\end{array}$ & $\begin{array}{c}z=-6.667 \\
p<0.001\end{array}$ & \\
\hline & 65 and more & $\begin{array}{c}z=-7.399 \\
p<0.001\end{array}$ & $\begin{array}{c}\mathrm{z}=-10.644 \\
\mathrm{p}<0.001\end{array}$ & $\begin{array}{c}\mathrm{z}=-10.363 \\
\mathrm{p}<0.001\end{array}$ & $\begin{array}{c}z=-9.694 \\
p<0.001\end{array}$ & $\begin{array}{c}\mathrm{z}=-4.800 \\
\mathrm{p}<0.001\end{array}$ \\
\hline \multirow[t]{5}{*}{ W } & $25-34$ & $\begin{array}{c}\mathrm{z}=-4.268 \\
\mathrm{p}<0.001\end{array}$ & & & & \\
\hline & $35-44$ & $\begin{array}{c}z=-6.742 \\
p<0.001\end{array}$ & $\begin{array}{c}\mathrm{z}=-8.051 \\
\mathrm{p}<0.001\end{array}$ & & & \\
\hline & $45-54$ & $\begin{array}{c}z=-6.382 \\
p<0.001\end{array}$ & $\begin{array}{c}\mathrm{z}=-8.502 \\
\mathrm{p}<0.001\end{array}$ & $\begin{array}{c}z=-6.155 \\
p<0.001\end{array}$ & & \\
\hline & $55-64$ & $\begin{array}{c}z=-7.441 \\
p<0.001\end{array}$ & $\begin{array}{r}\mathrm{z}=-10.470 \\
\mathrm{p}<0.001\end{array}$ & $\begin{array}{c}\mathrm{z}=-9.071 \\
\mathrm{p}<0.001\end{array}$ & $\begin{array}{c}z=-6.675 \\
p<0.001\end{array}$ & \\
\hline & 65 and more & $\begin{array}{c}z=-7.799 \\
p<0.001\end{array}$ & $\begin{array}{c}\mathrm{z}=-10.526 \\
\mathrm{p}<0.001\end{array}$ & $\begin{array}{c}\mathrm{z}=-9.428 \\
\mathrm{p}<0.001\end{array}$ & $\begin{array}{c}z=-7.795 \\
p<0.001\end{array}$ & ns. \\
\hline
\end{tabular}

Source: authors' own research.

Table 3. Education and the length of relationship. Mann-Whitney $U$ test results for multiple comparisons among men $(\mathrm{M}, \mathrm{N}=315)$ and women $(\mathrm{W}, \mathrm{N}=364)$ in relationships

\begin{tabular}{|c|c|c|c|c|}
\hline & Education & $\begin{array}{c}\text { Primary/ Lower } \\
\text { secondary }\end{array}$ & Vocational & Secondary \\
\hline \multirow[t]{3}{*}{$\mathrm{M}$} & Vocational & ns. & & \\
\hline & Secondary & $z=-3.552 p<0.001$ & $z=-2.146 p<0.001$ & \\
\hline & Higher & $\mathrm{z}=-4.253 \mathrm{p}<0.001$ & $z=-3.339 p<0.001$ & ns. \\
\hline \multirow[t]{3}{*}{ W } & Vocational & $z=1.982 p=0.047$ & & \\
\hline & Secondary & $\mathrm{z}=-3.097 \mathrm{p}=0.002$ & $\mathrm{z}=-2.146 \mathrm{p}<0.001$ & \\
\hline & Higher & $\mathrm{z}=-4.922 \mathrm{p}<0.001$ & $\mathrm{z}=-5.743 p<0.001$ & $\mathrm{z}=-2.996 \mathrm{p}<0.001$ \\
\hline
\end{tabular}

Source: authors' own research.

Table 4. Self-assessment and the length of relationship. Mann-Whitney U test results for multiple comparisons among men ( $\mathrm{M}, \mathrm{N}=315)$ and women $(\mathrm{W}, \mathrm{N}=364)$ in relationships

Financial situation

$\mathrm{Bad}$

Average

\begin{tabular}{clccc}
\hline M Average & ns. & \\
& Good & ns & $\mathrm{z}=-2.858 \mathrm{p}=0.004$ \\
\hline W Average & ns. & \\
& Good & $\mathrm{z}=-2.158 \mathrm{p}=0.031$ & $\mathrm{z}=-3.694 \mathrm{p}<0.001$
\end{tabular}

Source: authors' own research. 
Table 5. Socio-occupational group and the length of relationship. Mann-Whitney U test results for multiple comparisons among men $(\mathrm{M}, \mathrm{N}=315)$ and women $(\mathrm{W}, \mathrm{N}=364)$ in relationships

\begin{tabular}{|c|c|c|c|c|c|c|c|}
\hline & $\begin{array}{l}\text { Socio- } \\
\text { occupational } \\
\text { group } \\
\end{array}$ & $\begin{array}{c}\text { Managers } \\
\text { and } \\
\text { specialists }\end{array}$ & $\begin{array}{c}\text { Middle-level, } \\
\text { services and } \\
\text { office staff }\end{array}$ & Labourers & $\begin{array}{c}\text { Self- } \\
\text { employed } \\
\text { farmers } \\
\end{array}$ & $\begin{array}{c}\text { Housewives, } \\
\text { househusbands } \\
\text { and } \\
\text { unemployed }\end{array}$ & $\begin{array}{c}\text { Retirees } \\
\text { and } \\
\text { pensioners }\end{array}$ \\
\hline \multirow[t]{6}{*}{ M } & $\begin{array}{l}\text { Middle-level, } \\
\text { services and office } \\
\text { staff }\end{array}$ & ns. & & & & & \\
\hline & Labourers & ns. & $\begin{array}{l}\mathrm{z}=-3.337 \\
\mathrm{p}=0.001\end{array}$ & & & & \\
\hline & $\begin{array}{l}\text { Self-employed } \\
\text { farmers }\end{array}$ & ns & $\begin{array}{l}z=2.474 \\
p=0.013\end{array}$ & ns. & & & \\
\hline & $\begin{array}{l}\text { Househusbands } \\
\text { and unemployed }\end{array}$ & $\begin{array}{r}\mathrm{z}=-2.217 \\
\mathrm{p}=0.027\end{array}$ & $\begin{array}{c}z=-2.924 \\
p=0.003\end{array}$ & ns. & ns. & & \\
\hline & $\begin{array}{l}\text { Retirees and } \\
\text { pensioners }\end{array}$ & $\begin{array}{c}\mathrm{z}=-7.962 \\
\mathrm{p}<0.01\end{array}$ & $\begin{array}{c}z=-10.390 \\
p<0.001\end{array}$ & $\begin{array}{c}z=-6.777 \\
p<0.001\end{array}$ & $\begin{array}{c}z=-8.340 \\
p<0.001\end{array}$ & $\begin{array}{l}z=-4.364 \\
p<0.001\end{array}$ & \\
\hline & $\begin{array}{l}\text { Pupils and } \\
\text { students }\end{array}$ & ns & ns & $\begin{array}{c}z=-2.221 \\
p=0.026\end{array}$ & $\begin{array}{c}\mathrm{z}=-2.088 \\
\mathrm{p}=0.037\end{array}$ & ns. & $\begin{array}{c}z=-3.523 \\
p<0.001\end{array}$ \\
\hline \multirow[t]{6}{*}{ W } & $\begin{array}{l}\text { Middle-level, } \\
\text { services and office } \\
\text { staff }\end{array}$ & ns. & & & & & \\
\hline & Labourers & ns. & ns. & & & & \\
\hline & $\begin{array}{l}\text { Self-employed } \\
\text { farmers }\end{array}$ & ns. & $\begin{array}{c}z=-2.273 \\
p=0.023\end{array}$ & ns. & & & \\
\hline & $\begin{array}{l}\text { Housewives and } \\
\text { unemployed }\end{array}$ & ns. & ns. & ns. & $\begin{array}{c}\mathrm{z}=-2.074 \\
\mathrm{p}=0.038\end{array}$ & & \\
\hline & $\begin{array}{l}\text { Retirees and } \\
\text { pensioners }\end{array}$ & $\begin{array}{c}z=-8.762 \\
p<0.001\end{array}$ & $\begin{array}{c}z=-9.774 \\
p<0.001\end{array}$ & $\begin{array}{c}z=-7.139 \\
p<0.001\end{array}$ & $\begin{array}{c}z=-6.309 \\
p<0.001\end{array}$ & $\begin{array}{c}z=-9.494 \\
p<0.001\end{array}$ & \\
\hline & $\begin{array}{l}\text { Pupils and } \\
\text { students }\end{array}$ & $\begin{array}{c}z=-3.821 \\
p<0.001\end{array}$ & $\begin{array}{c}\mathrm{z}=-3.428 \\
\mathrm{p}=0.001\end{array}$ & $\begin{array}{c}z=-3.843 \\
p<0.001\end{array}$ & $\begin{array}{c}\mathrm{z}=-4.173 \\
\mathrm{p}<0.001\end{array}$ & $\begin{array}{l}z=-3.747 \\
p<0.001\end{array}$ & $\begin{array}{c}z=-6.317 \\
p<0.001\end{array}$ \\
\hline
\end{tabular}

Source: author's own research.

\section{Gender and orientation towards the (im)permanence of a relationship}

The proposed analytical approach to recognizing the attitude to the (im)permanence of a relationship from the perspective of readiness to remain in a relationship or to end it was displayed by representatives of all types among the respondents. Of the four orientations towards the (im)permanence of a relationship, two had a clear profile regarding the future of the relationship - one of them had a high potential for separation, while the other had a small one, thereby guaranteeing the relationship's permanence. The other two weighed the arguments for each option without clearly determining the future of the relationship. The research results showed that the largest number of respondents were in favour of one of these possibilities (indifference) - their decision to persist in an unsatisfactory relationship was determined by a kind of passivity; despite their orientation towards temporality, their readiness to remain in a relationship was low. They indicated 
a few reasons that would lead them to leave, and a few reasons which they would consider when thinking about whether or not to remain in an unsatisfactory relationship (37.8\%). The second most frequent attitude was that which expressed a high degree of readiness to break up - it took into account many reasons to end a failed relationship and at the same time not many to continue (acceptance). $28.2 \%$ of respondents would adopt this attitude to separation if they were in an unsatisfactory relationship. Fewer respondents (18.4\%) exemplified the orientation expressing a high degree of readiness to remain in a relationship while maintaining a high level of relationship requirements - no compromise in the event of a relationship crisis (ambivalence). The respondents most rarely identified with the orientation expressing the least potential for separation - they found many arguments for staying in a relationship despite the lack of satisfaction with it and at the same time despite a crisis situation arising in the relationship, few reasons would persuade them to end it (15.7\%) (inertia).

Gender differentiated the attitude to relationship permanence $(\mathrm{chi}=8.845$; $\mathrm{df}=3, \mathrm{p}=0.031 ; \mathrm{V}=0.102)$. A clear difference between men and women in this respect was noticeable only in the case of orientation indicating a high degree of readiness for separation (acceptance). In the situation of dissatisfaction with a relationship, women more often than men did not give up the high requirements of relationships, and at the same time indicated a few possible reasons for staying in a relationship. Therefore, women representing this orientation had the greatest potential for separation among the respondents.

For both women and men, showing a specific orientation towards the (im)permanence of a relationship in a situation of dissatisfaction was associated with their socio-demographic characteristics. Among men, the differentiating factor was age $(\mathrm{chi}=32.919 ; \mathrm{df}=15, \mathrm{p}=0.005 ; \mathrm{V}=0.167)$, education $(\mathrm{chi}=17.744$; $\mathrm{df}=9, \mathrm{p}=0.038 ; \mathrm{V}=1.123$ ) and self-assessment of financial situation ( $\mathrm{chi}=19.368$; $\mathrm{df}=6, \mathrm{p}=0.004 ; \mathrm{V}=0.157)$. Among women, the attitude to (im)permanence of a relationship also varied depending on age $(\mathrm{chi}=47.606$; $\mathrm{df}=15, \mathrm{p}=0.000$; $\mathrm{V}=0.187)$ and education ( $\mathrm{chi}=18.876 ; \mathrm{df}=9, \mathrm{p}=0.026 ; \mathrm{V}=0.118)$. The dynamics of change was also associated with the woman's socio-occupational category ( $\mathrm{chi}=41.332 ; \mathrm{df}=18, \mathrm{p}=0.001 ; \mathrm{V}=0.175)$.

On the basis of the results, it can be concluded that in the case of men the orientation with the lowest potential for separation (inertia) was represented by $14.7 \%$ of respondents. This type of orientation was typical of the oldest men (its incidence increased with the age of the respondents), more often with primary/ lower secondary or vocational education. Men who assessed their financial situation as good were the least likely to adopt this orientation.

Men most often (40.7\%) adopted the indifferent orientation. This type of orientation meant the absence of making a decision to end the relationship and a low degree of readiness to remain in an unsatisfactory relationship. It was demonstrated 
primarily by men with higher education and who made the highest assessments of their financial situation.

$23.9 \%$ of men expressed the separation orientation (acceptance). Actions aimed at ending the relationship in the event of dissatisfaction were most often undertaken by men with secondary education, who most often assessed their financial situation as bad.

Every fifth respondent (20.7\%) showed an ambivalent attitude to separation. Men with a university degree were the least likely to be demanding in a relationship and permanence-oriented, i.e. considering many arguments for opposite scenarios.

For women, the orientation with the least potential for separation (inertia) was demonstrated by $16.6 \%$ of the respondents. Despite the dissatisfaction with the relationship, women from the oldest age category, the least educated, manual workers, as well as retirees and pensioners, would still remain in it. The frequency of this orientation increased with age and decreased with the level of education of women.

As with men, indifference was the most common orientation (35.3\%) among women. Women aged 35-44, housewives or the unemployed showed the lowest readiness to remain in an unsatisfactory relationship in the absence of decision to break up.

$31.8 \%$ of the respondents represented the orientation exemplifying a high degree of readiness to break up and low readiness to remain in a relationship if they were dissatisfied with it (acceptance). This type of orientation was usually characteristic of the youngest women (students). On the other hand, it was the least often represented by women with elementary/ low secondary school education, retirees and pensioners.

The orientation indicating ambivalence was found in $16.6 \%$ of the women surveyed. This type was most often represented by women with the lowest level of education, working as manual workers. The least frequent occurrence of this type was recorded among women aged 35-44 (Table 6). 
Table 6. Attitude to relationship (im)permanence and the socio-demographics of women $(\mathrm{N}=504)$ and men $(\mathrm{N}=447)$. Data in percentages

\begin{tabular}{|c|c|c|c|c|c|c|c|c|c|c|c|}
\hline \multirow{3}{*}{$\begin{array}{c}\text { Character- } \\
\text { istics }\end{array}$} & \multirow[b]{3}{*}{ Categories } & \multirow[b]{2}{*}{ W } & \multirow[b]{2}{*}{$\mathrm{M}$} & \multicolumn{4}{|c|}{ Women } & \multicolumn{4}{|c|}{ Men } \\
\hline & & & & INR* & IND & $\mathrm{ACC}$ & AMB & INR & IND & $\mathrm{ACC}$ & AMB \\
\hline & & $\mathbf{5 3 . 0}$ & 47.0 & 16.6 & 35.3 & 31.8 & 16.2 & 14.7 & 40.7 & 23.9 & 20.7 \\
\hline \multirow{6}{*}{ Age } & $18-24$ & 7.3 & 8.1 & 3.0 & 21.2 & 63.6 & 12.1 & - & 28.6 & 37.1 & 34.3 \\
\hline & $25-34$ & 20.9 & 17.6 & 10.5 & 29.5 & 43.2 & 16.8 & 10.1 & 42.0 & 31.9 & 15.9 \\
\hline & $35-44$ & 19.7 & 17.6 & 14.1 & 44.6 & 33.7 & 7.6 & 10.6 & 39.4 & 28.8 & 21.2 \\
\hline & $45-54$ & 14.1 & 16 & 20.0 & 30.8 & 29.2 & 20.0 & 11.3 & 54.8 & 19.4 & 14.5 \\
\hline & $55-64$ & 17.1 & 19.4 & 20.3 & 40.5 & 19.0 & 20.3 & 22.9 & 37.3 & 19.3 & 20.5 \\
\hline & 65 or more & 21.0 & 21.3 & 25.6 & 35.6 & 18.9 & 20.0 & 22.5 & 37.5 & 16.3 & 23.8 \\
\hline \multirow{4}{*}{ Education } & $\begin{array}{l}\text { primary/ low } \\
\text { sec. }\end{array}$ & 18.2 & 19.7 & 23.7 & 23.7 & 23.7 & 28.9 & 16.0 & 40.7 & 18.5 & 24.7 \\
\hline & vocational & 17.9 & 31.9 & 18.5 & 35.8 & 32.1 & 13.6 & 20.0 & 37.5 & 20.8 & 21.7 \\
\hline & secondary & 32.5 & 28.2 & 15.8 & 35.5 & 34.9 & 13.8 & 9.2 & 34.9 & 32.1 & 23.9 \\
\hline & higher & 31.5 & 20.2 & 12.6 & 40.6 & 32.9 & 14.0 & 13.1 & 52.4 & 22.6 & 11.9 \\
\hline \multirow{5}{*}{$\begin{array}{l}\text { Place of } \\
\text { residence }\end{array}$} & village & 37.8 & 41.9 & 20.3 & 34.9 & 27.9 & 16.9 & 12.1 & 38.8 & 25.5 & 23.6 \\
\hline & town $<19000$ & 12.9 & 15.8 & 15.3 & 28.8 & 33.9 & 22.0 & 16.1 & 29.0 & 29.0 & 25.8 \\
\hline & $\begin{array}{l}\text { town } \\
20-99000\end{array}$ & 20.2 & 19 & 14.9 & 37.2 & 35.1 & 12.8 & 15.4 & 52.6 & 16.7 & 15.4 \\
\hline & $\begin{array}{l}\text { town } \\
100-499000\end{array}$ & 16.5 & 14.4 & 12.3 & 37.0 & 34.2 & 16.4 & 16.9 & 45.8 & 23.7 & 13.6 \\
\hline & city $>500000$ & 12.5 & 8.8 & 14.8 & 37.0 & 33.3 & 14.8 & 19.4 & 32.3 & 25.8 & 22.6 \\
\hline \multirow[t]{2}{*}{ Income** } & $\begin{array}{l}\text { Less than } \\
2000 \mathrm{zl}\end{array}$ & 72.5 & 64.8 & 16.5 & 29.1 & 37.9 & 16.5 & 14.7 & 39.7 & 25.0 & 20.6 \\
\hline & $2000 \mathrm{zl}$ or more & 27.5 & 35.2 & 16.5 & 38.4 & 27.5 & 17.6 & 13.8 & 40.2 & 23.4 & 22.6 \\
\hline \multirow{3}{*}{$\begin{array}{l}\text { Financial } \\
\text { situation }\end{array}$} & bad & 6.3 & 5.8 & 13.8 & 41.4 & 24.1 & 20.7 & 24.0 & 28.0 & 28.0 & 20.0 \\
\hline & average & 31.5 & 32.8 & 17.3 & 33.8 & 29.5 & 19.4 & 21.1 & 35.0 & 16.3 & 27.6 \\
\hline & good & 62.2 & 61.5 & 16.5 & 35.8 & 33.7 & 14.0 & 10.5 & 44.9 & 27.1 & 17.4 \\
\hline \multirow{7}{*}{$\begin{array}{l}\text { Socio- } \\
\text { occupational } \\
\text { group }\end{array}$} & $\begin{array}{l}\text { managers and } \\
\text { specialists }\end{array}$ & 13.3 & 10.6 & 17.5 & 38.6 & 28.1 & 15.8 & 9.1 & 57.6 & 18.2 & 15.2 \\
\hline & $\begin{array}{l}\text { middle-level, } \\
\text { services and } \\
\text { office staff }\end{array}$ & 19.3 & 18.8 & 7.8 & 37.8 & 40.0 & 14.4 & 7.2 & 36.2 & 34.8 & 21.7 \\
\hline & $\begin{array}{l}\text { labourers/ } \\
\text { manual workers }\end{array}$ & 8.1 & 14.5 & 24.3 & 24.3 & 27.0 & 24.3 & 14.1 & 42.4 & 24.7 & 18.8 \\
\hline & $\begin{array}{l}\text { self-employed } \\
\text { farmers }\end{array}$ & 7.4 & 9.3 & 19.4 & 30.6 & 44.4 & 5.6 & 12.8 & 42.6 & 23.4 & 21.3 \\
\hline & $\begin{array}{l}\text { Housewives, } \\
\text { househusbands, } \\
\text { unemployed }\end{array}$ & 16.9 & 12 & 10.7 & 42.7 & 32.0 & 14.7 & 15.4 & 34.6 & 34.6 & 15.4 \\
\hline & $\begin{array}{l}\text { Retirees and } \\
\text { pensioners }\end{array}$ & 30.7 & 31.8 & 22.2 & 37.8 & 20.7 & 19.3 & 23.0 & 36.9 & 15.6 & 24.6 \\
\hline & pupils students & 4.3 & 3.8 & 14.3 & 4.8 & 66.7 & 14.3 & - & 50.0 & 35.7 & 14.3 \\
\hline
\end{tabular}

* INR - inertion, IND - indifference, ACC - acceptance, AMB - ambivalence.

** missing data: men: $24.5 \%$; women $21.7 \%$.

Source: authors' own research 


\section{Discussion of the results and conclusions}

The analyses of the results of the conducted research have shown that the contemporary relationships of Poles are varied in terms of their form and length, and that relationship diversity among men and women depends on their sociodemographic characteristics. It has been established that the most popular model for life as a couple is a long-lasting marriage - long-term relationships predominate. This allows us to state that the linear order of the course of a relationship is still the dominant model. However, given that long-term relationships are mostly formed by older women and men, while being in informal and short-term relationships correlates with young age, it can be concluded that the temporary model of intimate relationships concerns primarily young men and women.

It is worth noting, however, that although the dominant relationship model is a long-term formal relationship, all respondents indicated at least one reason why they would be willing to end the relationship in a situation of crisis and dissatisfaction. These results justify the conclusion that regardless of the model of life as a couple, the existence of relationships has boundaries which are marked by dissatisfaction with the relationship, and separation is permissible. Therefore, it is reasonable to say that readiness to break up is one of the elements functioning in contemporary intimate relationships, and using the category of separation in the analysis of contemporary intimate relationships is well-founded.

The study has also shown that for both women and men the most common types of attitude to separation were indifference and acceptance. The analysis shows that the latter attitude - indicating a high degree of readiness to part - was much more often manifested by women. This result leads to the conclusion that women are more uncompromising if a crisis occurs in a relationship and it is unsatisfactory for them. This is in line with the findings of other researchers which show that women are more likely to file for divorce or, in the case of informal relationships, initiate separation (Jalovaara 2003).

The findings presented in the article correspond with the results of research on the causes of divorces, which indicate that the decision to separate depends on socio-demographic characteristics (see for example: Hills, Rubin, Peplau 1976; Amato 2000; Slany 2001; Jalovaara 2003). However, they propose a more detailed perspective. Gender is not one of the socio-demographic variables here, but it is the main axis of analysis and the criterion of description. This made it possible to show the diversity of attitudes to separation within gender groups, not only the differences between men and women. The analyses taking into account the structural approach to gender made it possible to determine which women and men - with which status characteristics - are more willing to separate. They also showed that most often, despite the lack of satisfaction with the relationship, older men with the lowest level of education and in a bad financial situation would remain in a relationship. Men with secondary education and rather low economic status 
would not remain in a failed relationship. In the case of women, those from the oldest age category, the least educated, inactive on the labour market, would not leave an unsatisfactory relationship. Most often the women who are the youngest, better educated, and studying, would decide to leave. The results obtained seem to indicate that women tend to prefer the Giddensian pure relationship model more than men, and when it does not meet their expectations, they are willing to end it. At the same time, it can be said that the idea of a pure relationship has its structural limitations, which were indicated by Beck and Beck-Gernsheim (1995) as being one of the most important limiting components limit in the transformation of marital-family life. The obtained results show that in the event of being in an unsatisfactory relationship, the readiness to break up was differentiated by social status - which was especially visible in the case of women. Younger, better educated women would more often decide to split up than the older, less educated ones with low incomes.

The research has confirmed the hypotheses. It was found that gender differentiates relationship experiences, but only in the scope of one of the dimensions analyzed, i.e. relationship length. It was established that women stay more often than men in shorter relationships. The structure of the intimate relationship status of respondents was similar among men and women.

The analyses that took into account the features of the social status within the gender category have revealed the diversity of relationship experiences among women and men. It has been shown that the intimate relationship status among men was differentiated by three socio-demographic characteristics: age, education and belonging to a socio-occupational group. Among women, however, the intimate relationship status of women was differentiated by most of the socio-demographic characteristics analyzed, i.e. age, belonging to a socio-occupational category, education, place of residence, and their self-assessment of their financial situation.

It was also found that the relationship between the variation in the relationship length among men and women depends on socio-demographic characteristics. Among men, a dependence was noted for such characteristics as: age, education, self-assessment of financial situation, income per person and the belonging to a socio-occupational group. A similar dependence was found for women - age, education, self-assessment of financial situation, and the socio-occupational category differentiated the length of relationships among women.

Gender has been shown to differentiate the attitude to relationship permanence. Showing a specific orientation towards the (im)permanence of the relationship was associated both for men and women with their socio-demographic characteristics. Among men, age, education and self-assessment of financial situation were of differentiating importance, while among women it was their age, education and socio-occupational category.

The findings from the research can contribute to the development of a new approach to the study of changes in marital-family life proposed in the framework of the sociology of intimacy (Jamies on 2008) or the sociology of the couple (see 
Schmidt et al. 2018). The results of the presented research can complement the sociological analyses of the functioning of the couple, in which it is emphasized that the individual who starts to build a relationship has a number of ideas about how it should function, what a successful relationship is and how their partner should behave. These images constitute a set of expectations for a relationship and most often come to light in conflict situations (Schmidt et al. 2018). The proposed analyses show that these expectations are well defined and the failure to meet them sets boundaries for the permanence of the relationship. Even if separating is not a real event in a relationship, in the event of failure to meet the partners' expectations it is considered as a potential event in crisis situations.

In addition, the analytical perspective presented here goes beyond existing approaches to the issue of separation, which boils down to the examination of divorced persons. The approach used in the analysis includes persons living in informal relationships as well as currently unmarried people. This approach is indicated as particularly desirable in the study of changes in modern martial-family life (see among others: Krumrei, Mahoney, Pargament 2009; Toth, Kemmelmeier, 2009; Afifi et al. 2013).

The research may also constitute an exemplification of the legitimacy of using perspectives in which gender is treated as a theoretical category and in which the structural consequences of gender differences are taken into account. As has been shown, this allows researcher not only to create an image of intimate life in selected aspects, but also to expand knowledge about women and men. It is also possible that the proposed study of changes in intimate life from the perspective of its temporary nature will lead to new sociological questions and reflections developed as part of research on socio-cultural time and the cyclical family (see among others: Adamski 2002; Dychtwald 2003; Strzelecka 2017 ) or those within the socio-temporal dimensions of intimate biographies (Lahad 2011; Paprzycka 2019).

\section{Bibliography}

Acker J. (1990), Hierarchies, Jobs, bodies: A Theory of Gendered Organizations, "Gender \& Society", no. 2, pp. 139-158.

Adamski F. (2002), Rodzina. Wymiar społeczno-kulturowy, Wydawnictwo Uniwersytetu Jagiellońskiego, Kraków.

Afifi T., Davis S., Denes A., Merrill A. (2013), Analyzing divorce from cultural and network approaches, "Journal of Family Studies", vol. 19, no. 3, pp. 24-53.

Amato P.R. (2000), The Consequences of Divorce for Adults and Children, "Journal of Marriage and Family", vol. 62, no. 4, pp. 1269-1287.

Bauman Z. (2003), Liquid Love: On the Frailty of Human Bonds, Polity Press, Cambridge.

Bawin-Lergos B. (2004), Families in Europe: A private and Political Satake - Intimacy and Solidarity, "Current Sociology", vol. 49, no. 5, pp. 49-65.

Beck U., Beck-Gernsheim E. (1995), The Normal Chaos of Love, transl. M. Ritter, J. Wiebel, Polity Press, Cambridge. 
Beck-Gernsheim E. (2002), Reinventing the Family. In Search of New Lifestyles, Polity Press, Cambridge.

Brown S.L. (2004), Moving from cohabitation to marriage: effects on relationship quality, "Social Science Research", vol. 33(1), pp. 1-19.

Collier J.F., Rosaldo M.Z., Yanagisako S. (2007), Czy rodzina istnieje? Nowe ujęcia antropologiczne, transl. A. Ostrowska, [in:] R.E. Hryciuk, A. Kościańska (eds.), Gender. Perspektywa antropologiczna, Wydawnictwo Uniwersytetu Warszawskiego, Warszawa, vol. 1, pp. 60-75.

Connell R. (1987), Gender and Power: Society, the Person and Sexual Politics, Stanford University Press, California.

Connell R. (2013), Socjologia ptci. Płeć w ujęciu globalnym, Wydawnictwo Naukowe PWN, Warszawa.

De Singly F. (1994), Fortuna e sfortuna della donna sposata. Sociologia della vita matrimoniale, transl. V. Cicchelli, Edizioni Dedalo, Bari.

De Singly F. (1996), Sociologia della famiglia contemporanea, Palomar Athenaeum, Bari.

Dychtwald M. (2003), Cycles. How We Will Live. Work and Buy, Free Press, New York.

Ferree M.M. (2003), Practice Makes Perfect?: A Comment on Yancey Martin's Gendering Practices, Practicing Gender, "Gender \& Society”, no. 3, pp. 373-378.

Giddens A. (2006), Przemiany intymności: seksualność, miłość i erotyzm we wspótczesnych społeczeństwach, transl. A. Szulżycka, Wydawnictwo Naukowe PWN, Warszawa.

Giddens A. (2007), The Global Revolution in Family and Personal Life, [in:] A.S. Skolnick, J.H. Skolnick (eds.), Family in Transition, Pearson, Boston, pp. 76-95.

Giddens A. (2010), Nowoczesność i tożsamość: “Ja” i spoleczeństwo w epoce późnej nowoczesno$s ́ c i$, transl. A. Szulżycka, Wydawnictwo Naukowe PWN, Warszawa.

Hills Ch., Rubin Z., Peplau L. (1976), Breakups Before Marriage: The End of 103 Affairs, "Journal of Socilal Issues", vol. 32, no. 2, pp. 147-168.

Holmes J., Marra M. (2011), Leadership discourse in a Maori workplace: negotiating gender, ethnicity and leadership at work, "Gender and Language", vol. 2, pp. 317-342.

Illouz E. (2016), Dlaczego miłość rani. Studium socjologiczne, Wydawnictwo Krytyki Politycznej, Warszawa.

Jalovaara M. (2003), The Joint Effects of Marriage Partners'Socioeconomic Positions on the Risk of Divorce, "Demography", vol. 40, no. 1, pp. 67-81.

Jamieson L. (1998), Intimacy: Personal Relationships in Modern Societies, Polity Press, CambridgeMalden.

Jamieson L. (2008), Od rodziny do intymności, [in:] P. Sztompka, M. Bogunia-Borowska (eds.), Socjologia codzienności, Wydawnictwo Znak, Kraków, pp. 115-142.

Jewdokimow M., Garncarek M. (2007), W pół kroku. Single o sobie samych, "Societas/ Communitas", no. 4-5(2), pp. 173-194.

Kaufmann J.C. (1993), Sociologie du couple (4 edition), Presses Universitaires de France, Paris.

Kaufmann J.C. (2005), Quando l'amore comincia, Societa Editrice il Mulino, Bologna.

Kaufmann J.C. (2012), Niezwykła historia szczęśliwej miłości, transl. A. Kapciak, Oficyna Naukowa, Warszawa.

Kiernan K. (2004), Cohabitation and Divorce across Nations and Generations, [in:] P.L. ChaseLansdale, K. Kiernan, R.J. Friedman (eds.), Human Development across Lives and Generations, University Press, Cambridge.

Krumrei E., Mahoney A., Pargament K.I. (2009), Divorce and the Divine: The Role of Spirituality in Adjustment to Divorce, "Journal of Marriage and Family", vol. 71, pp. 373-383.

Kwak A. (2014), Wspótczesny świat zmian - alternatywy dla malżeństwa, "Acta Universitatis Lodziensis. Folia Sociologica", no. 51, pp. 5-19. 
Kwak A., Bieńko M. (eds.) (2012), Wielość spojrzeń na matżeństwo i rodzinę, Wydawnictwa Uniwersytetu Warszawskiego, Warszawa.

Lahad K. (2011), Singlehood, Waiting, and the Sociology of Time, "Sociological Forum", vol. 27, no. 1, pp. 163-186.

Lenz K. (2006), Soziologie der Zweierbeziehung. Eine Einführung, Springer, Wiesbaden.

Majka-Rostek D. (2008), Związi homoseksualne. Studium socjologiczne, Difin, Warszawa.

Martin P.Y. (2004), Gender As Social Institution, "Social forces”, vol. 4, pp. 1249-1273.

Mizielińska J. (2017), Odmienne czy zwyczajne. Rodziny z wyboru w Polsce, Wydawnictwo Naukowe PWN, Warszawa.

Musiał M. (2015), Intymność i jej współczesne przemiany. Studium z filozofii kultury, Wydawnictwo Universitas, Kraków.

Paprzycka E. (2019), Biografie intymne singli - analiza typologiczna, [in:] K. Wąż (ed.), Obyczajowość seksualna Polaków. Perspektywa interdyscyplinarna, Oficyna Wydawnicza "Impuls", Kraków, pp. 135-177.

Plummer K. (2003), Intimate Citizenship: Private Decisions and Public Dialouges, University of Washington Press, Seattle-London.

Renzetti C.M., Curran D.J. (2008), Kobiety, mężczyźni i społeczeństwo, Wydawnictwo Naukowe PWN, Warszawa.

Schmidt F. (2015), Para, mieszkanie, malżeństwo: dynamika związków intymnych na tle przemian historycznych $i$ współczesnych dyskusji o procesach indywidualizacji, Wydawnictwo Naukowe Uniwersytetu Mikołaja Kopernika i Fundacja na rzecz Nauki Polskiej, Warszawa-Torun.

Schmidt F., Mizielińska J., Stasińska A., Olcoń-Kubicka M., Żadkowska M., Jasińska J., Halawa M. (2018), W stronę socjologii pary: propozycja paradygmatu teoretyczno-badawczego, "Studia Socjologiczne", vol. 3(230), pp. 12-39.

Silverstein L.B., Auerbach C.F. (2005), (Post)modern Families, [in:] J.L. Roopnarine, U.P. Gielen (eds.), Families in Global Perspective, Pearson, Boston, pp. 33-48.

Slany K. (2001), Alternatywne formy życia matżeńsko-rodzinnego w ponowoczesnym świecie, Zakład Wydawniczy Nomos, Kraków.

Slany K. (2006), Socjo-demograficzne aspekty “syndromu opóźniania” i jego konsekwencje dla polityki społecznej, "Roczniki Socjologii Rodziny. Studia socjologiczne oraz interdyscyplinarne”, vol. XVII, pp. 13-25.

Strzelecka C. (2017), Wpływ czasu społecznego na konstruowanie modeli życia rodzinnego, "Tematy z Szewskiej”, no. 219, pp. 7-19.

Szlendak T. (2011), Socjologia rodziny: ewolucja, historia, zróżnicowanie, Wydawnictwo Naukowe PWN, Warszawa.

Sztompka P. (2012), Socjologia. Analiza społeczeństwa, Wydawnictwo Znak, Kraków.

Toffler T. (2007), Szok przyszłości, transl. W. Osiatyński, E. Grabczak-Ryszka, E. Woydyłło, Kurpisz, Warszawa, pp. 206-217.

Toth K., Kemmelmeier M. (2009), Divorce attitudes around the world: Distinguishing the impact of culture on evaluations and attitude structure, "Cross-Cultural Research", no. 43, pp. 280-297.

Trybulec M. (2009), Nowe media a kulturowe doświadczenie czasu. Uwagi krytyczne na marginesie teorii akceleracji czasu, "Annales Universitatis Mariae Curiae-Skłodowska. Sectio I, Philosophia-Sociologia”, no. 34, pp. 7-19.

Walerstein J., Blakeslee S. (1989), Second Chances: Men, Women, and Children a Decade after Divorce, Ticknor \& Fields, New York.

Wharton A.S. (2006), The Sociology of Gender. An Introduction to Theory and Research, Blackwell Publishing, Malden-Oxford. 
Emilia Paprzycka

Edyta Mianowska

\title{
JAKIE KOBIETY (NIE) ODCHODZĄ, A JACY MĘŻCZYŹNI (NIE) ZOSTAJĄ? PLEĆ A RÓŻNORODNOŚĆ FORM I TEMPORALNOŚĆ WSPÓŁCZESNYCH ZWIĄZKÓW INTYMNYCH
}

\begin{abstract}
Abstrakt. Przedmiotem zainteresowania w artykule uczyniono doświadczenia w związkach w perspektywie różnorodności ich form i czasu trwania oraz orientacji partnerów na trwałość relacji. Ramy pojęciowe wyznaczała perspektywa socjotemporalna, a analizy prowadzono w odwołaniu do koncepcji usytuowanych w obszarze socjologii rodziny, socjologii intymności, socjologii płci oraz socjologii czasu. Celem badań było ustalenie zależności między cechami społeczno-demograficznymi a doświadczeniami w związkach (różnorodnością form i czasem trwania) oraz gotowością do pozostania lub rozstania w sytuacji kryzysu w związku kobiet i mężczyzn. Badania zrealizowano metodą sondażu diagnostycznego na reprezentatywnej próbie dorosłych Polaków w styczniu 2018 roku. Płeć okazała się różnicować staż związku i stosunek do trwałości związków. Ustalono, że kobiety częściej niż mężczyźni pozostają w krótszych związkach. Stwierdzono również, że doświadczenia kobiet z różnymi typami związków są bardziej zróżnicowane ze względu na status społeczny niż mężczyzn. Rozpoznano cztery typy orientacji na (nie)trwałość związku. Ustalono, że wśród mężczyzn gotowość do rozstania jest zróżnicowana przez wiek, wykształcenie i samoocenę warunków materialnych, a wśród kobiet przez wiek, wykształcenie i kategorię społeczno-zawodową.
\end{abstract}

Słowa kluczowe: związki intymne, rozstania, kobiety, mężczyźni, płeć, płeć kulturowa. 